\title{
Understanding Misunderstandings from Socio-cognitive Approach to Pragmatics
}

\author{
Zhou Honghui ${ }^{1}$, Chen Dongchun ${ }^{2}$ \\ ${ }^{1}$ School of Foreign Studies, Lingnan Normal University, Zhanjiang, China \\ ${ }^{2}$ School of Foreign Studies, Guangdong University of Finance and Economics, Guangzhou, China
}

Email address:

cdcch@163.com (Chen Dongchun)

\section{To cite this article:}

Zhou Honghui, Chen Dongchun. Understanding Misunderstandings from Socio-cognitive Approach to Pragmatics. International Journal of Language and Linguistics. Vol. 7, No. 5, 2019, pp. 194-201. doi: 10.11648/j.ij11.20190705.13

Received: June 20, 2019; Accepted: August 4, 2019; Published: August 19, 2019

\begin{abstract}
Misunderstanding is an old and open question especially in the linguistic domain, but few concerns have put on this important topic recently. To reconsider this problem and offer instructive views, the new theoretical perspective and approaches are needed. A new theory "socio-cognitive approach to pragmatics" (SCA) dubbed by Istvan Kecskes offers a fresh angle for understanding misunderstandings. Other than traditional pragmatics and cognitive pragmatics, SCA standing in the middle point tries to integrate them and explain linguistic phenomenon with both social and cognitive factors. This study tries to examine misunderstandings under SCA, especially its view of Common Ground Co-construction. First, it is assumed that the root cause of misunderstanding lies in egocentrism, which are both an intrinsic property of verbal communication and a mechanism of individual thinking. Then, with a detailed analysis of CG co-construction deficiency and misunderstandings from the perspective of CG co-constructionism of SCA, it is illustrated how egocentrism causes different misunderstandings. In so doing, this study digs out the root cause of misunderstanding by taking speaker and hearer as a whole, and considering both the social factors and cognitive factors, which is a fresh practice on the "speaker-hearer pragmatic model" of SCA.
\end{abstract}

Keywords: Socio-cognitive Approach to Pragmatics, The Root Cause of Misunderstanding, Egocentrism, CG Co-construct

\section{Introduction}

Misunderstanding is a common "untidy" verbal communication phenomenon, [1] which often has negative effects and even creates interpersonal conflicts, which requires more time and effort to resolve. Therefore, misunderstandings are often regarded as "errors" in verbal communication, which people should try to avoid in the traditional pragmatic view. However, in our daily life especially in casual talks, misunderstandings seem to be ubiquitous and difficult to avoid. This shows that misunderstandings are not "errors" in the general sense, and their essential roots deserve further study.

The root cause of misunderstanding has always been the focus of misunderstanding research. Previous studies have generally covered four aspects, namely the root of discourse, [2, $3]$ the root of context, [4, 5] the psychological roots [6-10] and Social roots. [11, 12] Recently, some researchers attempt to mine the root causes of misunderstandings from a comprehensive or an intercultural way. Wu from the angle of the language use system, namely, "the interference of psychological tendencies in the pragmatic inference process with reference to the Ideal Communication Model", [13] and from a philosophical perspective points out that "the intrinsic properties of the indicative and reflexive language and the subjectivity and psychological orientation of the communicator make the misunderstanding potentially in the process of communication, making the potential of misunderstanding a necessity." [14, 15] Intercultural impoliteness is a typical misunderstanding issue. Kecskes argues that impoliteness may work differently in intercultural interactions than in L1 communication. Such as for the propositional meanings, interlocutors with different L1 backgrounds may sometimes be unaware of impoliteness. [16-18]

Misunderstanding occurs in the stage of discourse comprehension, but what it reflects is a complete interactive communication process. As a kind of verbal communication phenomenon, it must also originate from and reflect the nature of communication. Therefore, we should explore the root cause of misunderstanding from the perspective of 
communicative nature and the overall process of communication, namely, taking speaker-hearer as a whole. From this point of view, Wu's research seems closer to this aim, and especially its research ideas are worthy of noticing and learning. However, the shortcoming is also obvious that it is biased by referring to the Ideal Communication Model (ICM), because this communication model itself is still arguable. [1, 6-8] The main point is that they think ICM puts too much weight on "cooperation", less even nothing on egocentric aspect of communication. So referring to ICM will hinder the objective and comprehensive analysis of misunderstandings from the perspective of the nature of communication.

"Socio-cognitive approach to pragmatics" (SCA) is a theoretical framework that advocates the integration of cognition and pragmatics, namely individual and social factors, "Cooperation" and "egocentrism" are the essential characteristics of the two opposites of communication. [1, 16-18] It proposes to construct "speaker-hearer pragmatics", aiming at constructing a kind of linguistics, which is also an analytical framework that combines pragmatic top-down approach and cognitive bottom-up approach. [19] SCA provides a new perspective for exploring the root causes of misunderstanding from the perspective of speaker-hearer as a whole and the nature of communication. This paper mainly aims to discuss the egocentrism of communication as the root cause of misunderstanding by means of Common Ground (CG) Co-construction in SCA.

\section{CG Co-construction in SCA}

For a long time, the concept of CG has been widely concerned by pragmatics research, and together with "cooperation" and "intentions", it is considered to be one of key factors in achieving successful communication. Therefore, CG has also become a heated topic of the theory of "egocentrism" dubbed by psycholinguistics. [20-22] And it has raised and opposed an important topic of Gricean theory, namely "Cooperation Principle". Thus, there form two opposite views on CG, Pragmatic views and Cognitive views. Pragmatic views argue that $\mathrm{CG}$ is a concrete representation of thinking that exists in the brain before communicative practice; $[23,24]$ while Cognitive perceptions believe that CG is a common working memory process with the characteristic of "emerging", and is a post factum of dynamic construction. [21] The essence of the argue lies in the opposition of the dynamic and static views of "common ground". Based on this, SCA put forward the view of "CG Co-construct", [25] which is summarized in the following three aspects.

1) SCA differentiates the core $C G$ and the emergent $C G$. The former refers to the relatively static and stable general knowledge shared by a specific language community, including encyclopedic knowledge, macro-social cultural knowledge and linguistic knowledge; the latter refers to relatively dynamic and variable individual knowledge, including "shared sense" and "current sense" among the specific communicative parties. The difference between individual shared information and core $\mathrm{CG}$ is that the sharing category is different. The former is social, and the latter is shared by specific communicators. [19] In other words, the latter depends more on the specific context, that is, emergent physical surrounding. SCA distinguishes the content of $\mathrm{CG}$ by the existence state of its constituent elements in specific verbal communication. It not only organically combines the static view and the dynamic view, but also reflects the status and role of different components from the pragmatic function, that is, the basicity and the sameness of the core CG, and the emerging and the temporary of the emergent CG.

2) SCA defines CG as an "assumption". It pointed out that $\mathrm{CG}$ is a thinking representation entity that is constructed (co-constructed) by both parties, but neither party can determine in advance whether the entity exists or not. In other words, it is difficult for people to conclude what the so-called "I know you know what I know" is, and essentially it is an estimate. [26] We also believe that, as the "cognitive context hypothesis" in Relevance Theory requires an ostensive-inferential process for mutual manifestation, and CG construction also requires a process of verifying hypotheses, in which there must be misunderstandings or incomprehension. [6] This requires cooperation between the two parties for eliminating misunderstandings, which embodies the property of dynamism of co-construction.

3) Methodologically, SCA offers some specific operational mechanisms of CG co-construction, namely, activating, seeking, and creating. [25]

(1) Ann: - Please check why the baby is crying.

(2) Ann: - See the woman with blonde hair? She's our new English teacher. She is pretty, isn't she?

(3) Teacher: - As you well know, I am leaving soon...

(4) Bud: - Ann, would you like to have dinner with me tonight?

Ann: - I'd love to, but I'll have to pick up my sister at the airport.

In example (1), "baby" plays a role in activating the thinking representation, and also activates other core CGs associated with the concept, such as the psychological needs of the baby, the social roles of the parents, the responsibilities of the parents, and the language skills of both parties. Cases (2) and (3) exemplify the method of seeking $\mathrm{CG}$, that is, the speaker intentionally highlights certain information by explicit means to achieve the purpose of mutual manifestation, as in example (2) "See the woman with blonde hair" takes the woman's clothing, appearance and temperament into a common vision. In the example (3), the teacher used the slogan "As you well know" to evoke a common memory. Not only that, some CGs can be created temporarily, as Ann in example (4), in the case of convincing that Bud did not know she had a sister, brought in the information "I have a sister" in order to create a new CG for subsequent discourse. It can be seen that in order to convert the CG hypothesis into mutual information, temporary dynamic co-construction is required. 


\section{The Root Cause of Misunderstanding: Egocentrism}

The concept of "egocentrism" is derived from the description of children's personality in Developmental Psychology. It refers to children's perception of the surrounding world from their own perspectives, focusing on their own perceptions, emotions, and subjective wills. [27] While Psycholinguistics describes "egocentrism" as a communicative feature that contrasts with Grice's "Cooperative Principle," [7, 8, 22] in which adults are often egocentric in interactive communication. In addition, cognitive linguistics believes that language is also egocentric, referring to the subjectivity of language, that is, "the self-expression of the speaker through words, including opinions, positions, attitudes, beliefs, etc." [22] In SCA, "egocentrism" of communication is not equivalent to the above concepts, especially the derogatory color and personality sense. It is an objective description of the characteristics of speech act or the mechanism of thinking mechanism, [19] is "a way of thinking that communicators automatically bring explicit information to the level of attention in the process of discourse output and understanding". [1]

SCA's interpretation of "egocentrism" is based on the integration of Keysar's "communicative egocentrism" and Giora's "salience hypothesis". [22] In Giora's view, "salience" is not only a cognitive model, but also a mechanism of thinking, that is, the more salient the meaning of the code formed in our brain due to habit, familiarity, frequency of use and typicality, the faster you get. Kecskes extended the "salience hypothesis" to distinguish "inherent salience" from "emergent salience". [1] The former refers to the vocabulary meaning defined by Giora, and the latter refers to situationality or perceptiveness. Perceptiveness highlights differentiation, as different people in the same situation will pay attention to different details. It can be seen that egocentrism in SCA actually refers to the essential attribute of the thinking mechanism of "salience", which is reflected in the verbal communication as the feature of communicative egocentrism. So far, the operation of the thinking mechanism cannot be observed in detail, but its properties are reflected by the communicative characteristics. Salience mechanisms drive the formation of egocentric cognition, which is manifested in self-perspective and self-cognition, inducing egocentric discourse. [26] Similarly, the egocentrism of communication is reflected in the communicative subject bias. And the use of the most familiar and most accessible information in cognitive resources for speech expression and understanding is a direct portrayal of the Principle of Least Effort of thinking in the process of verbal communication, which inevitably induces misunderstanding.

Specifically, verbal communication is a process of integration of individual cognition and social interaction. The egocentrism of communication will undoubtedly have a direct impact on these two processes, leading to egocentric understanding and perspective, referred to as "self- cognition" and "self-perspective". [29] Self-cognition is mainly reflected in the individual differences of knowledge and experience. Individual cognition is a process of "privatized" knowledge learning, [30] so it will be more or less subjective. Knowledge experience includes both core $\mathrm{CG}$ information and local shared information in emergent CG. They all derive from the communicator's prior contextualized experience, that is, information that has been reserved before the specific communication occurs. The self-cognition of core $\mathrm{CG}$ is mainly reflected in the deviation of vocabulary concept features, such as the Eskimo's cognition of snow, the Mongolian classification of horses, and etc. The self-cognition of local shared information in CG is mainly reflected in the difference of memory focus and intensity. The above constitutes the knowledge base for misunderstandings, especially inducing propositional misunderstanding. The emergence of "situational information" in CG is often reflected in the "self-perspective." The self-perspective has priority over the other perspective, [20] because, based on the Principle of Least Effort, it takes less time and effort to observe things and consider problems from self perspective. In addition, unlike the property of unconsciousness of the core $\mathrm{CG}$, the co-construction of emerging $\mathrm{CG}$ is often conscious and strategic, embodied in a perspective strategy, tending to express a subjective emotion, attitude and position, and therefore tends to induce referential misunderstanding, intention misunderstanding and implicated meaning misunderstanding. It can be seen that misunderstanding can be analyzed systematically from the egocentrism of communication. The following will further analyze it from the perspective of CG co-construction.

\section{Co-construction Failure and Misunderstanding}

For a long time, misunderstanding research is mostly focused on the listener. The reason is that normally people think that misunderstanding belongs to the listener and seems to have nothing to do with the speaker. The root cause of such view lies in the traditional verbal communication theory. Kecskes pointed out that traditional pragmatics theory usually regards communication as a cooperative, context-dependent process, in which the speaker is often conceived as the one who makes the discourse after considering all the contextual factors, hearer is conceived as the one who tries to understand the speaker's intentions as much as possible. [1] In fact, what the speaker intends to express is not always recovered by the hearer, but depends on the pre-context of both parties, especially the pre-individual context, the interaction of intention and attention, and the emergent CG. In other words, verbal communication is essentially a process of integration of individual factors and social factors, and symbiosis of cooperation and egocentrism. This is also the reason why SCA advocates speaker-hearer pragmatics.

As mentioned above, the idea "co-construction CG" provides an analytical mechanism for exploring the root cause 
of misunderstanding from the perspective of communicative nature and speaker-hearer as a whole. Under normal circumstances, verbal communicators, based on information dynamic co-construction, form common knowledge, achieve successful communication, and also thus construct new common information for subsequent conversations. It can be said that verbal communication is actually a continuum of mutual understanding and CG co-construction. Among them, the egocentrism of communication will inevitably lead to some co-construction failure phenomena, that is, the information imbalance occurs in the process of activating, seeking and creating, which leads to misunderstanding. With the advancement of the verbal flow, the participation of more construction factors, the self-monitoring and adjustment of the communicative subjects, and the CG co-construction will eventually be achieved, which is reflected in the dispelling of misunderstandings. Below we further distinguish the core CG co-construction failure and the emergent $\mathrm{CG}$ co-construction failure, combined with three construction methods to analyze misunderstanding.

\subsection{Core CG co-construction Failures and Misunderstandings}

The core CG is relatively static, stable, and built in a default way, so it is often seen as a presupposed knowledge. The core $\mathrm{CG}$, with the property of social sharing, is the basis of normal communication, and is the basis for ensuring the identity of the language community. [19] But its sharing is not absolute, is something of scope and degree. The "Dynamic Model of Meaning" points out that vocabulary concept include 3 parts: core conceptual features, specific semantic features, and specific cultural characteristics. [8] For example, "kick off" in "The president kicked off the new academic year with an excellent speech" includes core concept feature "announcement", semantic feature "metaphoric expression, more rhetorical effects than 'open', 'start", and cultural identity "American culture". The deviation of core CG is often reflected in the difference of vocabulary concept features, which will lead to co-construction failure and misunderstanding, including two situations: one is that the listener lacks the corresponding core concept information; the other is the difference between semantic features and specific cultural characteristics.

\subsubsection{Core Concepts Defect and Misunderstanding}

Normally linguistic representation (sound/shape) will activate the same conceptual features, but if the listener lacks the corresponding core concepts, which will lead to incomprehension or misunderstanding. For the former case, the listener often asks "What does XX mean?" which often occurs in second-language acquisitions; the latter occurs more in the native language conversation because the listener does not have the corresponding core concept. Under such circumstances, the interlocutors tend to make guesses according to the linguistic representations. Two examples from Chinese TV series China Land are illustrated as below.

(5) (A conversation between an old couple, Laoga and
Gashen, and his son Yongzhi about the daughter-in-law issue) 永志 1: 爹, 俺娶外面的媳妇行不行?

Yǒngzhì 1: Diē, ăn qǔ wàimiàn de xífù xíng bùxíng?

Yong Zhi 1: Daddy, how about marrying a girl from a far place?

老嘎 1: 要娶外面的媳妇? 你在外面有媳妇啦?

Lăo gā 1: Yào qǔ wàimiàn de xífù? Nǐ zài wàimiàn yǒu xífù la?

Laoga1: marry a girl away from here? Are you having a wife outside?

永志 2: 不是, 没结婚呢, 是女, 女朋友。

Yǒngzhì 2: Bùshì, méi jiéhūn ne, shì nứ, nứ péngyǒu

Yong Zhi 2: No, not married yet, just a...... a girlfriend.

嘎婶 1: 啥朋友?

Gā shěn 1: Shà péngyǒu?

Gashen 1: what friend?

永志 3: 女朋友

Yǒngzhì 3: Nü péngyǒu

Yong Zhi 3: Girlfriend.

嘎婶 2: 这, 这多不要脸的词, 你这, 啥叫女朋友, 你 说, 好好说。

Gā shěn 2: Zhè, zhè duō bùyào liăn de cí, nǐ zhè, shà jiào $n$ ü péngyǒu, nǐ shuō, hăohăo shuō.

Gashen2: what a shameless word! What does "nứ péngyǒu" mean, you, you explain it.

(6) (Japanese invaders were coming, villagers were moving back to the mountains)

老嘎: 栓子, 把王先生带到山上去, 和大牲口放在一起。

Lă o gā: Shuān zi, bă wáng xiānshēng dài dào shān shàngqù, hé dà shēngkǒu fàng zài yīqĩ.

Laoga: Suanzi, take Mr. Wang to the mountain and put him with the big cattle.

王先生：你说啥呢！把我和牲口放在一起?

Wáng xiānshēng: Nǐ shuō shà ne! Bă wǒ hé shēngkǒu fàng zài yīqũ?

Mr. Wang: What are you talking about? Put me and the cattle together?

永清（老嘎的儿子): 他说让你跟大牲口呆在一块, 在 我们这大牲口比啥都重要。

Yǒng qīng (lăo gā de érzi): Tā shuō ràng nǐ gēn dà shēngk ŏu dāi zài yīkuài, zài wǒmen zhè dà shēngkǒu bǐ shà dōu zhòngyào.

Yongqing (Laoga's son): He said that cattle are most important for us, staying with cattle is safer.

In example (5), obviously, Gashen (Mum) has no corresponding core concept of the new word "girlfriend" ("nupengyou" is a word in standard Chinese). Although she asked Yongzhi to explain it, actually she has already had her own understanding (see Gashen 2), that is, "girlfriend" is misunderstood as "mistress" or "illegal sexual partners". Similarly, in Example (6), Mr. Wang misunderstood Laoga's communicative intention as disrespect for him because he lacked the core CG of "staying safe with cattle" in this village (cattle are very important to farmers which are well protected). It can be seen that the absence of listener's core CG will not only lead to propositional misunderstanding like example (5), but also induce intentional misunderstanding like example (6). 


\subsubsection{Conceptual Deviation and Misunderstanding}

The concept deviation leads to the failure of $\mathrm{CG}$ co-construction and induces misunderstanding mainly in the different understanding of semantic features and cultural characteristics. The co-construction mechanism here is also based on "activating". Such misunderstandings are particularly prevalent in cross-regional and intercultural communication. Such as:

(7) (Groom Xiaozhou from Hunan and bride Xiaoyuan from Sichuan are having a wedding ceremony in Xiaozhou's home. The following is a dialogue between mother Zhou and Xiaoyuan)

周母 1: 小袁, 你父母来一趟不容易, 你看我们打发点 什么好呢?

Zhōu mǔ 1: Xiăo yuán, nǐ fümǔ lái yī tàng bù róngyì, nǐ kàn wǒmen dăfā diăn shénme hăo ne?

Mother Zhou 1: Xiaoyuan, it's not easy for your parents to come over so far. How do you think we should send them away?

小袁 1: 打发? 你把他们当成要饭的呀!

Xiăo yuán 1: Dăfā? Nǐ bă tāmen dàngchéng yàofàn de ya!

Xiaoyuan 1: Send away? You treat them like beggars!

周母 2: 没有呀, 我们这里结婚都要给亲家送打发的, 哦, 就是回礼。

Zhōu mǔ 2: Méiyǒu ya, wǒmen zhèlǐ jiéhūn dōu yào gěi qìngjiā sòng dăfā de, ó, jiùshì huílı̌.

Mother Zhou 2: Not like that, according to the tradition here, we have to send something back to the bride's parents. It's just a return gift.

小袁 2: 这样呀。

Xiăo yuán 2 : Zhèyàng ya.

Xiaoyuan 2: Ok, I see.

(8) Chinese student: I think Peter drank a bit too much at the party yesterday.

Turkish student: Eh, tell me about it. He always drinks much.

Chinese student: When we arrived he drank beer. Then Mary brought him some vodka. Later he drank some wine. Oh, too much.

Turkish student: Why are you telling me this? I was there.

Chinese student: Yes, but you told me to tell you about it. [1]

For example (7), the word "dafa" has the same core conceptual feature of "giving something to someone", but there are differences in semantic color due to regional diversity. Xiaoyuan, Sichuan daughter-in-law, thinks that the word has a derogatory meaning of "giving alms to beggars", while Mother Zhou, speaking Hunan dialect, thinks that it is just equivalent to a polite term "Huili" (send a present in return), which leads to misunderstanding. In Example (8), "tell me about it" is a situation-bound utterance (SBUs for short). [17] Its prominent meaning is pragmatic one, similar to "saying yes" in Chinese. Because Chinese students do not understand the specific cultural characteristics of the utterance, they interpret it literally and misunderstand Turkish students' communicative intentions. Similar situations are common in cross-cultural communication. For example, foreigners who are new to Chinese often misunderstand the Chinese SBU "chi le ma?"(Have you eaten yet?). The real intention behind this SBU is just greeting, nothing with "inviting for a dinner".

\subsection{Emergent CG co-construction Failures and Misunderstandings}

The emergent $\mathrm{CG}$ refers to relatively dynamic and changeable individual knowledge, including "individual shared information" and "contextual information". The former is mainly based on "activating" and the latter is mainly "seeking" and "creating". The main problem of the emergent CG co-construction lies in the effective coordination of locally shared information and instant information, that is, the key factor is whether or not the other party can successfully recall the sharing information, and notice the specific situation focus or the new information created. Generally speaking, the richer the shared information, the more effective and smooth the communication is. For example, for the husband and wife, an eye contact is enough to know each other's intention. But because of the differences in memory, attention and interest, interlocutors cannot always achieve perfect accordance every time. This will led to the emergent CG co-construction failures and misunderstandings.

\subsubsection{Local Shared Information Co-construction Failures and Misunderstandings}

(9) (Zheng \& zhou are good friends, encountering on the road)

郑 1：你的事情搞定了没?

Zhèng 1: Nǐ de shìíng găodìngle méi?

Zheng 1: Did you get it done?

周 1: 单位倒是联系好了, 但原单位领导卡住不放。

Zhōu 1: Dānwèi dăoshì liánxì hăole, dàn yuán dānwèi lǐ ngdăo kă zhù bù fàng.

Zhou 1: The unit is well connected, but I am stuck by the former unit leader.

郑 2: 是吗? 这个你没跟我说过。不过我不是问这个, 是问你去台湾开会签注的事。

Zhèng 2: Shì ma? Zhège nǐ méi gēn wǒ shuōguò. Bùguò wǒ bùshì wèn zhège, shì wèn nǐ qù táiwān kāihuì qiānzhèng de shì.

Zheng 2: Is it? You didn't tell me this. But I am not asking this. I am asking you the visa issue to Taiwan.

周 2: 哦, 对, 你上次问的是这个事, 最近好多事, 有 点乱。

Zhōu 2: Ó, duì, nǐ shàng cì wèn de shì zhège shì, zuìjìn hă oduō shì, yǒudiăn luàn.

Zhou 2: Oh, yes, last time you asked about this, you see a lot of troubles, a bit messy.

(10) (the dialogue between Laoga and his wife Gatsao in the TV series China Land)

嘎嫂 1: 你到底咋了?

Gā săo 1: Nǐ dàodǐ zăle?

Gatsao 1: What is wrong with you?

老嘎 1: 我这心里空落落的。

Lăo gā 1: Wǒ zhè xīnlǐ kōngluòluò de 
Laoga 1: I feel very upset.

嘎嫂 2: 唉, 这七巧妹子也是走了这么长时间了，连个 信也不来。

Gā săo 2: Āi, zhè qī qiăo mèizi yěshì zǒule zhème cháng shíjiānle, lián gè xìnyě bù lái.

Gatsao 2: Well, Sister Qiqiao has been away for so long without even a letter.

老嘎 2: 你想哪儿去了你。

Lăo gā 2: Nǐ xiăng nă'er qùle nǐ.

Laoga 2: Nonsense! You think too much!

嘎嫂 3: 那你空落落的为啥呀?

Gā săo 3: Nà nǐ kōngluòluò de wèi shà ya?

Gatsao 3: Then why are you so upset?

老嘎 3: 我想起曹军长来了。

Lăo gā 3: Wǒ xiăngqǐ cáojūn zhăng láile.

Laoga 3: I missed Commander Cao just then.

In example (9), Zhou and Zheng are good friends and undoubtedly have a lot of personal information to share. However, frequent information exchanges make the specific memory confused. In addition, Zheng did not specify what "things" refer to, which leads to the local shared information co-construction failure and misunderstanding. In example (10), Sister Qiqiao is Laoga's lover, and Commander Cao is Laoga's confidant. This is the local information shared between Laoga and his wife. So the wife's point of view on Laoga's melancholy mood is egocentric and Laoga's intention is misunderstood ( $\mathrm{Ga} 2$ ). This also shows that in the process of CG co-construction, listeners are not always passively activated, but their subjectivity and initiative will also cause misunderstandings.

\subsubsection{Situational Information Co-construction Failures and Misunderstandings}

As the Chinese poem says "Héng kàn chéng lǐng cè chéng fēng, yuănjìn gāodī gè bùtóng" (looking at the mountain from different angles and distances, one will get different views), interlocutors in a same place will have the difference between the focus of attention and the perspective in the communicative situation. The inclusion of contextual factors in the concept of "CG co-construction" not only fully reflects the dynamics of co-construction, but also reveals the subjective differences between the two sides' observational perspectives. On the one hand, as Kecskes said, only the situational factors that enter the attention of both parties are well-known; [1] on the other hand, as the local shared information is co-constructed, the necessary prompting means are also indispensable. However, in the specific communication, the attention of both parties is still difficult to achieve perfect coordination, which is related to the attention of the communicator and the interference of cognitive tasks.

(11) (Wang Peng and his friends climbed to the top of the mountain near Leifeng Pagoda to overlook the West Lake)

朋友 1 : 真漂亮!

Péngyǒu 1: Zhēn piàoliang!

Friend 1: How beautiful!

王鹏 1: 是呀, 人间天堂嘛。

Wáng péng 1: Shì ya, rénjiān tiāntáng ma.
Wang Peng 1: Yes, paradise on earth !

朋友 2: 还有比人家天堂更美的, 你看......应该是杭州 美眉吧。

Péngyǒu 2: Hái yǒu bǐ rénjiā tiāntáng gèng měide, nǐ kàn......yīnggāi shì hángzhōu měiméi ba.

Friend 2: There's a thing more beautiful than paradise, look at it... look at that pretty Hangzhou girl.

王鹏 2: 恩, 是不错, 人家名花有主啦, 看到旁边那个 帅哥没, 西湖才是大家的, 好好欣赏吧。

Wáng péng 2: Ń, shì bùcuò, rénjiā míng huā yǒu zhǔ la, kàn dào pángbiān nàgè shuàigē méi, xīhú cái shì dàjiā de, hăohăo xīnshăng ba.

Wang Peng 2: Well, she is really beautiful. But the flower has its owner. Look at the handsome man next to her. The West Lake is for everyone. Enjoy yourself!

(12) (The father wants to go home by bus, and his son-in-law is showing him the station from a tall building)

女婿 1: 爸爸, 你看到那个高高的烟囱了吗?

Nüxù 1: Bàba, nǐ kàn dào nàgè gāo gāo de yāncōngle ma?

Son-in-law 1: Dad, do you see that tall chimney?

岳父 1: 看到了。

Yuèfù 1: Kàn dàole.

Father-in-law 1: Yes.

女婿 2: 车站就在烟图的前面。

Nüxù 2: Chēzhàn jiù zài yāncōng de qiánmiàn.

Son-in-law 2: The station is in front of the chimney.

岳父 2: 前面? 烟图前面不是海湾吗? (烟图靠近海湾)

Yuèfù 2: Qiánmiàn? Yāncōng qiánmiàn bùshì hă iwān ma?(Yāncōng kàojìn hăiwān)

Father-in-law 2: Front? Isn't the Bay in front of the chimney?

(The chimney is near the bay)

女婿 3: 我的意思是靠我们这边的前面。

Nüxù 3: Wǒ de yìsi shì kào wǒmen zhè biān de qiánmiàn.

Son-in-law 3: I mean the front of our side.

岳父 3: 这样呀, 那应该说是烟图的后面呀, 不对, 应 该是前面, 也不对, 反正你应该说得具体一点。

Yuèfù 3: Zhèyàng ya, nà yīnggāi shuō shì yāncōng de hòumiàn ya, bùduì, yīnggāi shì qiánmiàn, yě bùduì, fãnzhèng nǐ yīnggāi shuō dé jùtǐ yīdiăn.

Father-in-law 3: Well, that should be the back of the chimney. No, it should be the front or..... Anyway, you should be more specific.

In the case of (11), what the friend said "truly beautiful" refers to the beautiful girl climbing together, and Wang Peng is enjoying the beauty of the West Lake, not paying attention to the new information created by friends through the seeking mechanism (by his blinks and gestures). There have been co-construction failures so as to lead misunderstandings (see Wang Peng 1). In the case of (12), the "front" of the son-in-law refers to the front of the chimney facing them, while the father-in-law means that the chimney is facing away from them, forming a failure and misunderstanding of co-construction. Although the son-in-law has created a new focus of attention (see Son-in-law 1 and Father-in-law 1), egocentric orientation indicators such as "this", "that", "before" and "post" often differ depending on the perspective adopted by the subject, and thus become blurred and 
ambiguous.

In addition, the psychological space also has a difference in perspective. The transformation of psychological perspective often has a pragmatic function of expressing subjective emotions, positions and attitudes. For example, using "I come to the hospital" instead of "I go to the hospital" reflects the sympathy and concern of the speaker. On the contrary, if the listener fails to perceive the perspective change of the speaker, he cannot truly understand his emotional intentions, and it is likely to cause co-construction failure and misunderstanding.

(13) (In the TV series Snow Leopard: Japanese special forces are coming to attack Zhao village)

周卫国 1: 赵老伯, 这里不安全, 赵庄您也回不去了, 您赶紧带着乡亲转移吧。

Zhōuwèiguó 1: Zhào lăobó, zhèlǐ bù ānquán, zhào zhuāng nín yě huí bù qùle, nín gănjǐn dàizhe xiāngqīn zhuănyí ba.

Zhou Weiguo 1: Uncle Zhao, it's not safe here. You can't go back to Zhao village either. You should take the villagers to transfer as soon as possible.

赵老伯 1: 周团长, 我们马上就转移, 绝不会给八路军 添麻烦。

Zhào lăobó 1: Zhōu tuán zhăng, wǒmen măshàng jiù zhuă nyí, jué bù huì gěi bālùjūn tiān máfan.

Uncle Zhao 1: Regimental commander Zhou, we will transfer immediately and will never cause trouble to the Eighth Route Army.

周卫国 2: 赵老伯, 我不是这个意思。您别误会。我们 八路军不会擞下老百姓不管的。

Zhōuwèiguó 2: Zhào lăobó, wǒ bùshì zhège yìsi. Nín bié wùhuì. Wǒmen bālùjūn bù huì piē xià lăobăixìng bùguăn de.

Zhou Weiguo 2: Uncle Zhao, I don't mean that. Don't get me wrong. Our Eighth Route Army will not leave the people behind.

(14) (Dialogue in the modern drama Thunderstorm)

贵 1: 大少爷, 您是明天起身吗?

Guì 1: Dà shàoyé, nín shì míngtiān qǐ shēn ma?

Gui 1: Sir, are you leaving tomorrow?

萍 1: 嗯。

Píng 1: Ń.

Ping 1: Yes.

贵 2: 让我送送您。

Guì 2: Ràng wǒ sòng sòng nín.

Gui 2: Let me see you off.

萍 2: 不用, 谢谢你。

Píng 2: Bùyòng, xièxiè nǐ .

Ping 2: No, thank you.

贵 3: 不时总是您心好, 照顾着我们。您这一走, 我同 我这个头都得惦记着您了。

Guì 3: Bùshí zǒng shì nín xīn hăo, zhàogùzhe wǒmen. Nín zhè yī zǒu, wǒ tóng wǒ zhè yātou dōu dé diànjìzhe nínle.

Gui 3: You are always kind and take care of us. I and my daughter will miss you when you leave.

萍 3: (笑)你又没钱了吧?

Píng 3: (Xiào) nǐ yòu méi qiánle ba?

Ping3: (Laughter) Are you broke again?

贵 4: 大少爷, 您这可是开玩笑了。一我说的是实话, 四凤知道, 我总是背后说大少爷好的。
Guì 4: Dà shàoyé, nín zhè kěshì kāiwánxiàole.-Wǒ shuō de shì shíhuà, sì fèng zhīdào, wǒ zǒng shì bèihòu shuō dà shàoyé hăo $\mathrm{d}$

Gui 4: You're kidding, sir. — I'm telling the truth. As Sifeng knows, I always say that my young master is good.

In the case of (13), the Regimental commander Zhou Weiguo was informed that in Zhao village there was Japanese poison gas bomb. From the perspective of Zhao village's security, he asked Uncle Zhao to transfer quickly, but it was inconvenient to tell him the reason in case of causing riots among villagers. On the contrary, Uncle Zhao, standing in Zhou's shoes, misunderstood his intention as worrying that the people would cause trouble to the troops. Similarly, in the case of (14), Zhou Ping, based on his prior experience and acquaintance on Lu Gui and from the perspective of Lu Gui, misunderstood his good intentions as asking for awards (see Ping 3, 4).

\section{Conclusion}

This paper has explored the root cause of misunderstanding by using a new perspective of social-cognitive pragmatics. Firstly, it briefly reviews the CG con-construction of SCA, pointing out its definition, nature, content and construction method, which provide an analytical mechanism for the root cause of misunderstanding. Then, combined with the concept "egocentrism" of philosophy and cognitive science, we further discussed this concept under the theoretical frame of SCA, which points out that the root cause of misunderstanding lies in the egocentrism of communication. It also analyzed the formation of misunderstanding from perspective of $\mathrm{CG}$ co-construction, including core CG co-construction failure and the emergent CG co-construction failure. The study found that egocentrism can offer an overall explanation on different misunderstandings: on the one hand, the speaker can only, from the self-cognition and self-perspective, estimate the information that the hearer knows; on the other hand, listener, based on the prior knowledge and situational focus and attention, can only draw some related association and reasoning according to the linguistic representation. The result is that although both parties have the willingness to cooperate to accomplish a conversation, there is no guarantee that all explicit-inferential processes can achieve a state of mutual understanding, and certain CG co-construction failures and misunderstandings are inevitably come into being. This research is based on the pragmatic view of taking speaker-hearer as a whole, and makes a new interpretation of the root cause of misunderstanding. It has carried out preliminary practice on SCA's "speaker-hearer pragmatic model", which is conducive to further study of misunderstandings and other verbal communication issues.

\section{Acknowledgements}

This project is sponsored by the Key Project-A Study of Chinese SBUs from the Perspective of Ritual Theory of Interpersonal Relations (GD17WYZ19) supported by 
Guangdong Philosophy and Social Science Foundation.

\section{References}

[1] Kecskes, I. The paradox of communication: Socio-cognitive approach to pragmatics [J]. Pragmatics \& Society, 2010a. (1): 50-73.

[2] Verdler, Z. Understanding misunderstanding [A]. In Dale Jamieson (ed.). Language, Mind and Art [C]. Dordrecht/Boston/London: Kluwer Academic Publishers, 1994 9-21.

[3] Schegloff, E. A. Some sources of misunderstanding in talk-in-interaction [J]. Linguistics, 1987 (25): 201-218.

[4] Richard, L. A. The Philosophy of Rhetoric [M]. London: Oxford University Press, 1964.

[5] Taylor, T. J. Mutual Misunderstanding: Scepticism and the Theorizing of Language and Interpretation [M]. Duke University Press, 1992.

[6] Sperber, D. \& D. Wilson. Relevance: Communication and Cognition [M]. Oxford: Blackwell, 1995.

[7] Keysar, B. Communication and miscommunication: The role of egocentric processes [J]. Intercultural Pragmatics, 2007 (4-1): 71-84.

[8] Keysar, B. Egocentric processes in communication and miscommunication [A]. In Istvan Kecskes and Jacob Mey (eds.). Intention, Common Ground and the Egocentric Speaker-Hearer [C]. Mouton de Gruyter, 2008: 277-296.

[9] Zong Shihai. On the Social Psychological Roots of Misunderstanding [J]. Modern Foreign Languages, 2003 (3): 266-274.

[10] Zong Shihai. On the Formation Mechanism of Misunderstanding [J]. Foreign Language Teaching and Research, 2005 (2): 124-131.

[11] Gumperze, J. J. Discourse Strategies [M]. Cambridge: Cambridge University Press, 1982a.

[12] Tannen, D. You Just Don't Understand: Women and Men in Conversation [M]. New York: Ballantine Books, 1990.

[13] Grice, P. Logic and conversation [A]. In P. Grice (ed.). Studies in the Way of Words [C]. Cambridge: Harvard University Press, 1989: 22-40.

[14] Wu Yaxin. Interference of Psychological Tendency in Pragmatic Inference: Cognitive Roots of Misunderstanding [J]. Foreign Language Teaching, 2011 (1): 24-28.

[15] Wu Yaxin. The Potentiality of Speech Misunderstanding: Philosophical Thinking [J]. Studies in Philosophy of Science and Technology, 2012 (6): 17-21.
[16] Kecskes, I. Intercultural Impoliteness [J]. Journal of Pragmatics, 2015 (86): 43-47.

[17] Kecskes, I. Situation-Bound Utterances in Chinese [J]. East Asian Pragmatics, 2015 (1): 107-126.

[18] Kecskes, I. Context-sensitivity and impoliteness in intercultural communication [J]. Journal of Politeness Research, 2017 (13-1): 7-31.

[19] Zhou Honghui, Ran Yongping. A New Perspective of Social-Cognitive Pragmatics [J]. Foreign Language and Foreign Language Teaching, 2012 (4): 6-10.

[20] Keysar, B. \& B. Bly. Making sense of how we make sense: The paradox of egocentrism in language use [A]. In H. L. Colston \& A. N. Katz (eds.). Figurative Language Comprehension : Social and Cultural Influences [C]. London: Lawrence Erlbaum Associates, 2005: 131-151.

[21] Barr, D. \& B. Keysar. Mindreading in an exotic case: The normal adult human [A]. In B. Malle \& S. Hodges (eds.). Other Minds: How Humans Bridge the Divide Between Self and Other [C]. New York: Guilford Press, 2005.

[22] Giora, R. On Our Mind: Salience, Context, and Figurative Language [M]. Oxford: Oxford University Press, 2003. Clark, H. Using Language [M]. Cambridge: Cambridge University Press, 1996

[23] Stalnaker, R. Assertion [J]. Syntax and Semantics, 1978 (9): 315-332.

[24] Clark, H. \& S. Brennan. Grounding in communication [A]. In L. Resnick, J. Levine \& S. Teasley (eds.). Perspectives on Socially Shared Cognition [C]. Washington: American Psychological Association, 1991.

[25] Kecskes, I. \& F. Zhang. Activating, seeking and creating common ground: A socio-cognitive approach $[\mathrm{J}]$. Pragmatics and Cognition, 2009 (2): 331-355.

[26] Zhou Honghui. Cognitive Study of Egocentric Discourse and Its Roots [J]. Modern Foreign Languages, 2013 (1): 40-46.

[27] Piaget Ingeld. Wu Fuyuan Translated. Child Psychology [M]. Beijing: The Commercial Press, 1980.

[28] Lyons, J. Semantics [M]. Cambridge: Cambridge University press, 1997.

[29] Shen Jiaxuan. Subjectivity of Chinese and Teaching of Chinese Grammar [J]. Chinese Learning, 2009 (1): 3-12.

[30] Kecskes, I. Dueling context: a dynamic model of meaning [J]. Journal of Pragmatics, 2008 (40): 385-406. 